\title{
EFFECT OF OUCHI THEORY Z ON THE PERFORMANCE OF SELECTED MICROFINANCE BANKS IN WARRI METROPOLIS IN DELTA STATE
}

\author{
Agbele George (Ph.D) ${ }^{1}$ and Onoriode Omorho Humphrey ${ }^{2}$ \\ Delta State Polytechnic, Ozoro \\ ${ }^{1}$ Email: georgeashams@gmail.com \\ 2Email: onoriodehumphrey@yahoo.co.uk
}

Cite this article:

Agbele G., Onoriode O.H. (2021), Effect of Ouchi Theory $\mathrm{Z}$ on the Performance of Selected Microfinance Banks in Warri Metropolis in Delta State. British Journal of Management and Marketing Studies 4(2), 54-59. DOI: 10.52589/BJMMS-VAPFDIS.

\section{Manuscript History}

Received: 29 March 2021

Accepted: 21 April 2021

Published: 3 May 2021

Copyright $\odot 2020$ The Author(s). This is an Open Access article distributed under the terms of Creative Commons AttributionNonCommercial-NoDerivatives 4.0 International (CC BY-NC-ND 4.0), which permits anyone to share, use, reproduce and redistribute in any medium, provided the original author and source are credited.

\begin{abstract}
The study focused on the effect of Ouchi theory $Z$ on the performance of selected Microfinance Banks in Warri Metropolis in Delta State. The hypothetical aim was to ascertain the type of relationship that exists between the variables. The population covered 50 staff (Senior and Junior) of the selected Microfinance Bank in the area under study. The instrument employed for data collection was through personal (face-to-face) discussion with the respondents. Positive and reliable results were obtained. The data was analyzed through tables and chisquare statistical technique. The findings revealed that negative correlation exists between Ouchi theory $Z$ and performance of Microfinance Bank. Calculated value less than the critical value $(0.722<3.84)$ was equally Observed. This connotes a negative relationship between the dependent and independent variable. Microfinance banks in the area under study have been operating independently without the application of Ouchi theory $Z$ that encourages workers/employees satisfaction that result in an increase in productivity. The study recommended that team work should be encouraged among Microfinance Bank. There should be employee participation in decision making and strategic planning among Microfinance Banks. Again, constant and continuous communication (CCC) leadership style should be maintained between employees and employers of Microfinance Banks for maximum productivity.
\end{abstract}

KEYWORDS: Ouchi Theory Z, Organizational, Performance, Microfinance Bank. 


\section{INTRODUCTION}

Technology change is very dynamic, so it should be taken into consideration and provision should be made for flexibility for future changes or expansion to meet up with the competitions and the new technology changes (Nwafor, 2007). Emphasis is on technology in almost all sectors - economic, agriculture, health, productivity, communication and information etc., because of the digitized world. Many organizations today pay $99 \%$ of their attention to the Eperformance system in their work place while the remaining $1 \%$ is for the interest of the worker/employees. This, at the end of the day, ended in futility in their operations. Ouchi's theory $\mathrm{Z}$ of 1981 proves this idea wrong. The theorist is of the opinion that technology alone cannot move an organization forward and that if technology fails, it is advisable to think of alternative resorts. He suggests that a management style that puts the interests of the workers first yields maximum productivity. One of the implications of Ouchi theory $\mathrm{Z}$ is that loyalty and commitment of the employee is not negotiable, the leadership style and organizational structure is very essential. Some managers are very rigid and complex, which makes it impossible to get the best from the worker. They are not humane enough to listen to the plight of the employees. This attitude will continue to encumber with the growth and development of organization. Does our culture harmonize or bring ideas together that will necessitate performance in organization? This study intends to evaluate the application of Ouchi's theory $\mathrm{Z}$ to the challenges of Microfinance Banks in Warri Metropolis in Delta State for maximum productivity.

\section{Purpose of the Study}

The aim of the study is to evaluate the effect of Ouchi's theory $\mathrm{Z}$ on the selected Microfinance Banks in Warri Metropolis.

\section{Hypothesis}

$\mathrm{H}_{0}$ : Negative significant relationships exist between the Ouchi's theory $\mathrm{Z}$ and Microfinance banks in the area under study.

$\mathrm{H}_{1}$ : $\quad$ Positive significant relationships exist between Ouchi's theory $\mathrm{Z}$ and performance of Microfinance Banks in the area under study.

\section{Ouchi Theory Z Concept}

Ouchi theory $\mathrm{Z}$ is of the opinion that life is give and take and that if management of any organization expects total loyalty and commitment of employees, they should also get ready to take adequate care of the employee both on duty and off duty. The theorist is of the opinion that adequate care of the employees will lead to their commitment to duty. This theory was developed by William Ovili in the 80's using the Japanese management approach. In the 80's and when it became obvious that American must be flexible in their management style to be able to excel and meet the foreign competition of Japan, Europe, China etc., Theory $\mathrm{Z}$ workers will put in their best if the management can also pay close attention to their wellbeing.

According to (Idemobi, 2010), the secret of Japanese success according to Ouchi was not technology but a special way of managing people. "This is a managing style that focuses on a strong company philosophy, a distinct corporate culture, long-term staff development and consensus decision making (Ouchi, 1981)". The theorist emphasized on how employee loyalty 
and respect for the organization can increase through satisfying them in the workplace and even off-duties. Organizations today make policies upon policy on how best the organization can break-even or achieve maximum productivity through the available resources. But surprisingly there is no policy on how to get the best from the employees through adequate care and satisfaction. The potentiality of an employee can duly be discharged in a favourable working environment. Employee that is stressed-up, unhappy, hungry, dissatisfied with the work system can never give the company the best in him/her. Spending all money in the company to buy the best equipment without a prepared and trained individual in mind will amount to total waste for the organization.

In a landmark study of Nnewi management system by Idemobi (2005), it was revealed that Nnewi entrepreneur employed a management system of properly focused organization goals with quality leadership, enormous confidence and trust by employees and employers alike, closeness of employees and management involvement of subordinates in job problem solving, intimacy and familiarity in the workplace and elaborate welfare provisions (Idemobi, 2010). There was a symbiotic method of operation between the employees and employers, utmost confidence among them that in best operation was equally maintained among them. Ouchi's theory $\mathrm{Z}$ is of the view that in making decisions, planning, making policies, developing leadership style and adopting any organizational structure, the satisfaction of the worker must be prioritized for better performance.

\section{Ouchi Theory $\mathrm{Z}$ and Organizational performance of Microfinance Bank}

Organizational performance can be measured in several ways depending on the industry of interest ((Amstrong, 2006). Although the concept of organizational performance is very common in academic literature, its definition is not yet a universally accepted concept (Gaurea, IIies\&Stegereen, 2011; Gitonga, Kamara \& Orwa, 2016). Ouchi theory Z emphasizes on the need for workers satisfaction through leadership style, making and development of staff in order to achieve the set goal. Microfinance Bank provides small-scale financial services to micro entrepreneurs through group lending, progressive lending, regular payment schedules and collateral substitutes (Binuy, etal 2020). In providing financial aids and services to micro entrepreneurs and small sized businesses is to assist them achieve their goals. Actually, the services that Microfinance organization render to smaller organizations is enormous, but the bank itself is not making meaningful progress either because of the poor management style and the culture of the organization that is not making the employees put in their best. If Microfinance banks want to remain in the competitive market, this management style should be adopted. Over the years, the organizations remain in one spot because the potentials of their employees were sidelined. A cordial relationship and confidence among workers bring out the best in an individual.

\section{MATERIALS AND METHOD}

Research Design: Descriptive survey design was employed for the study. Through this method, information is obtained for testing hypotheses. Field research was conducted and data collected was subjected to statistical tools selected for the study (Chi-square). 
Source of Data: Both primary and secondary sources of data were adopted for the study because we used questionnaire instruments and literatures, journals, published textbooks and articles respectively.

Population: The population comprises 50 Senior and Junior staff of the selected Microfinance Banks in Warri Metropolis of Delta state. Questions were administered to the selected respondents by the researcher through face-to-face discussion method. The responses to the questions by the respondents were positive and reliable because of the relentless follow-up method adopted.

Data Analysis: Data was analyzed through the use of tables and chi-square statistical tools.

$\mathrm{X}^{2}=\frac{(F o-F e)^{2}}{F e}$

\section{Testing Hypothesis}

$\mathrm{H}_{0}$ : The application of Ouchi's theory $\mathrm{Z}$ of management does not improve the performance of Microfinance Banks in the area under study.

$\mathrm{H}_{1}$ : The application of Ouchi's theory $\mathrm{Z}$ of management improves the performance of Microfinance Banks in the area under study.

Table 1: Observed Frequency

Ouchi's theory Z and Microfinance Bank

\begin{tabular}{|l|l|l|l|}
\hline Attributes & Senior Staff & Junior Staff & Total \\
\hline Agree & 15 & 12 & 27 \\
\hline Disagree & 10 & 13 & 23 \\
\hline Total & 25 & 25 & 50 \\
\hline
\end{tabular}

To solve for expected frequency:

Solve for the Cells

Cell $11=\frac{25 \times 27}{50}=13.5$

Cell $12=\frac{25 \times 27}{50}=13.5$

Cell $21=\frac{25 \times 23}{50}=11.5$

Cell $22=\frac{25 \times 23}{50}=11.5$

Calculating for $\mathrm{X}^{2}=\frac{(F O-F e)^{2}}{F e}$

$X^{2}=\frac{15(13.5)^{2}}{15.5}+\frac{12(13.5)^{2}}{15.5}+\frac{10(11.5)^{2}}{11.5}+\frac{13(11.5)^{2}}{11.5}$

$X^{2}=0.166+0.166+0.195+0.195$ 
$X=0.722$

Critical $X^{2}$

Degree of Freedom (DF)

Df $=($ Row -1$)($ Column -1$)$

$\mathrm{Df}=(\mathrm{r}-1)(\mathrm{C}-1)$

$\mathrm{Df}=(2-1)(2-1)$

Df $=1 \times 1=1$ is the degree of freedom $(\mathrm{df})$

Critical value of $X^{2}$ of 0.5 level of significant with degree of freedom df 1.3 .84 is greater than the calculated value of 0.722 . Null hypothesis is retained.

\section{DISCUSSION OF FINDINGS}

From the application of chi-square analysis method $\left(\mathrm{X}^{2}=\frac{(F o-F e)^{2}}{F e}\right)$, it was observed that a higher value of 3.84 was obtained for critical table value and 0.722 for the calculated value $(3.84>0.722)$. By implication, it connotes that the application of Ouchi's theory $\mathrm{Z}$ of management does not relate with the performance of Microfinance Banks in the area under study. It suggests that the application of Ouchi's theory $\mathrm{Z}$ that improves productivity is not being considered by Microfinance Banks, and this also suggests that lower productivity may continue to be on the increase in Microfinance Banks if they fail to consider this theoretical principle of management.

\section{CONCLUSION AND RECOMMENDATION}

The study focused on the application of Ouchi's theory Z on the organizational performance of selected Microfinance Banks in Warri Metropolis in Delta State, Nigeria. From the discussion of finding, it was ascertained that the Microfinance Bank in the area under study has been operating independently. In other words, there was no strong or positive relationship between Ouchi's theory Z and performance of Microfinance Bank. This also suggests negative correlation between the dependent and the independent variables because Ouchi theory $\mathrm{Z}$ encourages increase in productivity. There might be low productivity among Microfinance Bank if the cordial relationship that enhances productivity between employer and employee is not acknowledged.Based on that, we recommend that:

1. Team work should be encouraged.

2. There should be employee participation in decision making and strategic planning among Microfinance Bank.

3. Constant and continuous communication (CCC) leadership style must be maintained between employers and employees among Microfinance Banks directors for maximum productivity. 


\section{REFERENCES}

Armstrong, M. (2006).Armstrong's Handbook of Performance Management. An evidencebased guide to delivering high performance, Kogan Page Publishers.

Binugom, Etal (2020) Business Model and Organizational performance of Microfinance Bank in Oyo State Nigeria. Global Scientific Journal (GSJ), Volume 8, May 2020.

Gavres, C. Ilies, L. \&Stegerean, R. (2011). Determinants of Organizational performance: The case of Romania, Management and Marketing. 6 (2) 285 - 300.

Gitonga, D. W., Kamara M. \&Orwa G. (2016). The Role of Cultural Diversity on the performance of Telecommunication firms in Kenya. International Journal of Management and Economics Invention. 2 (1) 640 - 655.

Idemobi, E. I. (2010). Theory and Practice of Management.First published 2010 by: Gobtak Printing and Pub.Co. Ltd. Enugu - Nigeria.

Ouchi, W. G. (1981). Theory Z: How American Business can meet the Japanese challenge Reading Addison Wesley. 